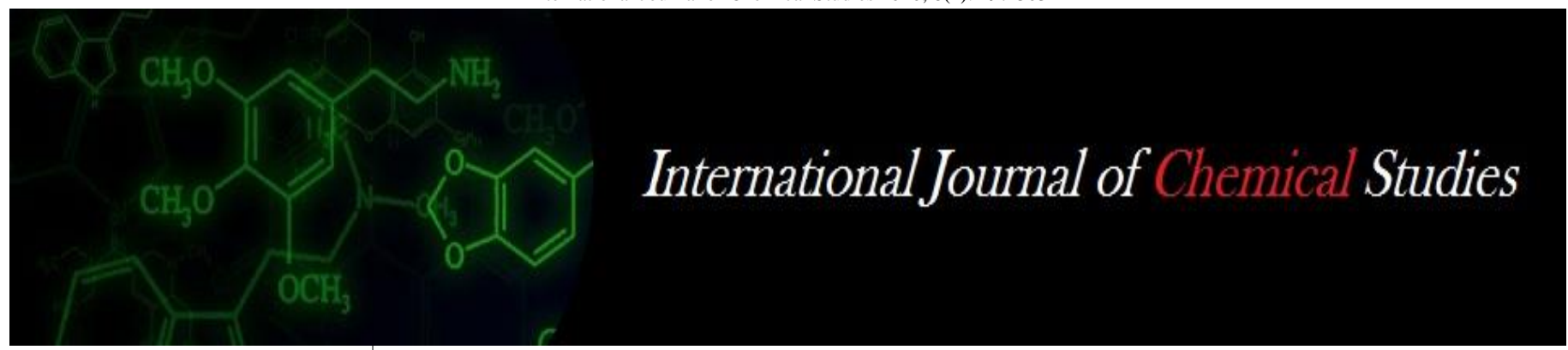

P-ISSN: 2349-8528

E-ISSN: 2321-4902

www.chemijournal.com

IJCS 2020; 8(2): 297-303

(C) 2020 IJCS

Received: 03-01-2020

Accepted: 07-02-2020

Deshmukh Sonali Lahu

Ph.D., Scholar Department of

Animal Husbandry and Dairy

Science, College of Agriculture,

Vasantrao Naik Marathwada

Krishi Vidyapeeth, Parbhani,

Maharashtra, India

Londhe Gajendra Kondiba

Head, Department of Animal

Husbandry and Dairy Science,

College of Agriculture, Vasantrao

Naik Marathwada Krishi

Vidyapeeth, Parbhani,

Maharashtra, India
Corresponding Author: Deshmukh Sonali Lahu Ph.D., Scholar Department of Animal Husbandry and Dairy Science, College of Agriculture, Vasantrao Naik Marathwada Krishi Vidyapeeth, Parbhani, Maharashtra, India

\section{Effects of incorporation of whey protein concentrate on Physicochemical, sensory, textural and microbial evaluation of developed Jowar Papadi}

\author{
Deshmukh Sonali Lahu and Londhe Gajendra Kondiba
}

DOI: $\underline{\text { https://doi.org/10.22271/chemi.2020.v8.i2e.8783 }}$

\begin{abstract}
Preparation of protein enriched Jowar Papadi by supplementing with Whey Protein Concentrate (WPC) at different levels of substitution, to assess the nutritional quality, storage stability and overall acceptability of the product. The products were analyzed for physicochemical, colour, textural, microbial and sensory attributes. Control and four experimental treatments were prepared with varying proportion of WPC-2.5 parts, 5 parts, 7.5 parts and 10 parts. Physicochemical analysis revealed that 10 parts of WPC supplemented Papadis shows maximum moisture content $(4.95 \%)$, fat content $(2.13 \%)$, protein content $(18.78 \%)$ and ash content $(3.08 \%)$ also minimum carbohydrate content $(71.07 \%)$ as compared to control. The total plate count, yeast and mold count of all samples of Jowar papadi was under acceptable limits. Jowar Papadi supplemented with 5 parts of WPC showed maximum overall acceptability (8.55). Lightness $\left(\mathrm{L}^{*}\right)$ value of fried Jowar papadi decreased from 65.89 to 56.86 . Whereas $\mathrm{a}^{*}$ and $\mathrm{b}^{*}$ value increased from 1.63 to 8.54 and 21.67 to 31.79 , respectively. Oil absorption and Expansion ratio increased as the WPC level increased. Texture analysis revealed that 10 parts of WPC supplemented fried Jowar papadi shows maximum Hardness $(0.34 \mathrm{Kg})$ and Fracturability $(0.228 \mathrm{~mm})$.
\end{abstract}

Keywords: WPC, Jowar papadi, physico-chemical, microbial and sensory properties

\section{Introduction}

Cereals and millets form the basic diet for millions of people throughout the world. They are superior in nutritional quality as these abundant resources contain some of the essential minerals, vitamins, sterols, growth factors and dietary fiber thus satisfying essential nutrient needs of mankind (Chavan and Kadam, 1989) ${ }^{[5]}$. India, being a huge country has been the home of innumerable religious order of human population and diversity in climatic conditions has resulted in a large number of fermented foods. Most of them remain majority secretive in their preparation being passed on from generation to generation and tend to be regionalized with many of them being only on the home scale by using back slopping. (Rolle and Satin, 2002) ${ }^{[19]}$. Fermentation enhances digestibility, flavor and aroma of food and exerts health promoting benefits through biological enrichment of food substrates with protein, essential amino acids, essential fatty acids and vitamins. (Hamad and Fields, 1979) ${ }^{[9]}$.

India is the home to the greatest population of severely malnourished children in the world. Childhood malnutrition is a massive crisis caused by a combination of factors including inadequate or inappropriate food intake. The malnourishment of India are located in urban, but more so in rural, areas where income and food variety is lower. According to the National Family Health Survey of India, 55 per cent of children living in rural areas suffer from malnutrition compared to 45 per cent of children in urban areas. A large percentage of population lives in rural communities with 70 per cent of the population living in villages. The Indian diet consists of curries and bean dishes mostly and a large amount of cereals such as wheat, rice, millet and corn. Compared with the recommendations of the World Health Organization, only $44.4 \mathrm{~g}$ of protein out of $60 \mathrm{~g}$ necessary is reached daily on an average by Indian (www.worldfoodprize.org). The protein deficiency is a major public health problem affecting an estimated 190 million preschool-age children, mostly from Africa and South-East Asia. Inadequate intakes of protein at infants developing age could lead to Protein Energy Malnutrition (PEM), which, when severe, may cause death or increase the risk of illness and mortality from childhood infections such as measles and those causing diarrhea (WHO, 2011) ${ }^{[22]}$. 
The majority of people in India are economically poor and thus, food choices for a balanced diet are further restricted by poverty and insufficient supply of nutritious foods. Therefore, it becomes important to focus on promoting maximal use of locally available inexpensive foods rich in protein, calcium, iron, fiber etc. (Rekha et al., 1999) ${ }^{[18]}$. Under these circumstances, the effective use of traditional processing methods, locally available and inexpensive food is very essential (Mitha and Mogra, 2007) ${ }^{[12]}$. It is essential that science and traditional knowledge should go together to find mutually beneficial results. Whey proteins are an excellent source of dietary nitrogen and branched chain amino acids which are used to fuel working muscles and stimulate protein synthesis. They also act as techno-functional ingredients in many formulated food systems due to their good solubility, surface activity and gelling properties (Chatterjee and Kanawjia, 2010) [4]. Whey can be incorporated advantageously into various food formulations, including cookies, breads, cake, crackers, pasta, confectionary products, ice creams, soups and gravies, frozen desserts beverages infant food formulations and special dietetic food (Munaza et al., 2012) ${ }^{[13]}$. Use of Whey Protein Concentrate in

preparation of cereal based traditional products would not only improve the product quality but also provide essential nutrients mostly proteins. Considering the importance of cereal based traditional products and nutritive profile of Whey Protein Concentrate it was decided to study on "Development of Protein Enriched Cereal Based Traditional Products by Incorporation of Whey Protein Concentrate."

\section{Material and Methods}

WPC were procured from Modern Dairy Ltd. Karnal, India. Jowar grains (Sorghum bicolor) cultivar variety Parbhani Moti (SPV 1411) was procured from Sorghum Research Station, VNMKV, Parbhani. Chemicals (Analytical grade) were procured from Viraj Enterprises, Parbhani. The glassware's required for conducting chemical analysis and preparation of product were utilized from laboratory of department of AHDS.

\subsection{Preparation of Jowar Papadi Flow diagram for preparation of protein enriched Jowar Papadi}

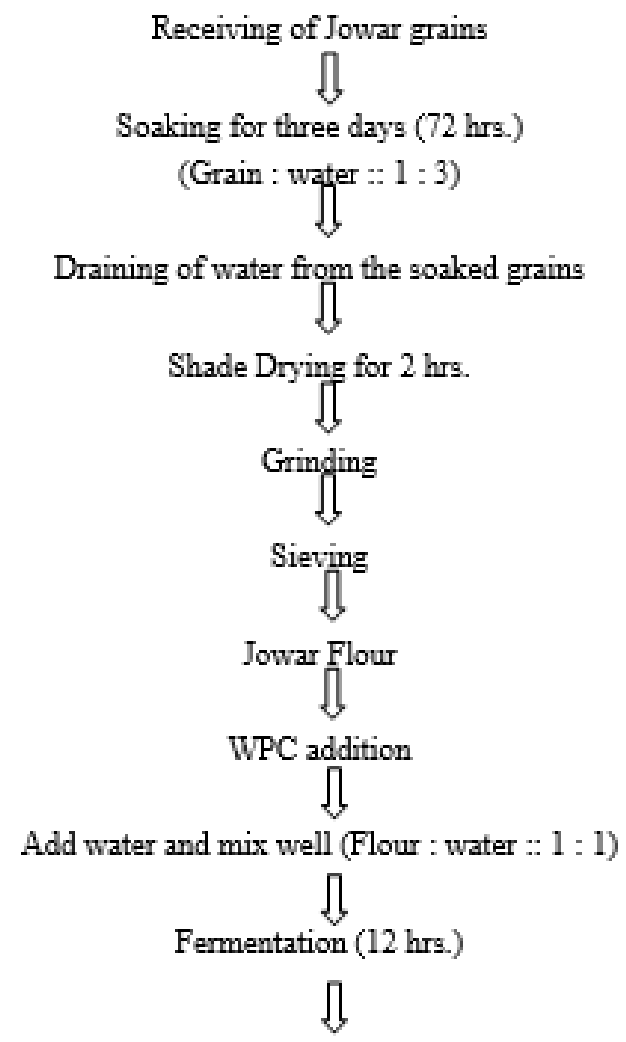

Salt- $5 \%+$ Cumin- $2.5 \%$

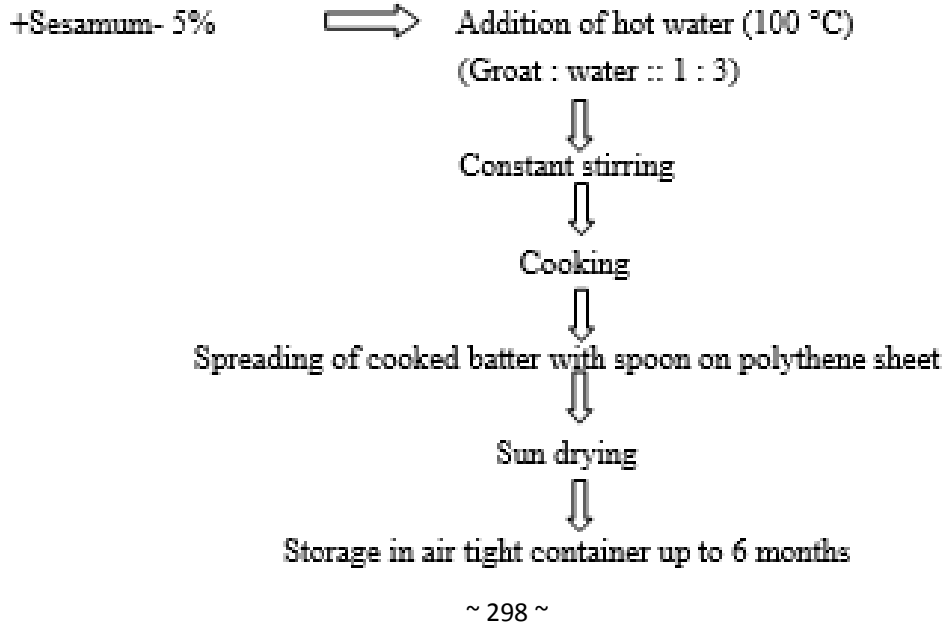




\subsection{Analytical studies}

\subsubsection{Physical characteristics of Jowar papadi}

Total Number of Papadi

The total number of papadi obtained from $100 \mathrm{~g}$ of Jowar grains flour and WPC were prepared and recorded. For each treatments in four times.

\subsubsection{Chemical Characteristics}

Chemical parameters like $\mathrm{pH}$, titratable acidity, protein, ash, fat, carbohydrate, moisture content, were determined by AOAC, $1990^{[1]}$.

\subsubsection{Microbiology of Papadi}

All samples was analyzed for different microbial counts such as total plate count, yeast and mold count and coliform count by adopting standard procedures.

\subsubsection{Organoleptic characteristics of fried protein enriched papadi}

The fried Protein Enriched fried Papadi was subjected to organoleptic characteristics like colour and appearance, body and texture (mouth feel), flavour and overall acceptability by scoring method using 9 point Hedonic scale.

\subsubsection{Physical properties of fried protein enriched papadi 2.2.5.1. Colour of Papadi}

Colour was measured in terms of $\mathrm{L}^{*}, \mathrm{a}^{*}$ and $\mathrm{b}^{*}$ values $\mathrm{L}^{*}$ is known as lightness and extends from 0 (black) to 100 (white). The other two co-ordinates $\mathrm{a}^{*}$ and $\mathrm{b}^{*}$ represent redness $(+60)$ to greenness (-60) and yellowness $(+60)$ to blueness $(-60)$ respectively were recorded.

\subsubsection{Oil absorption}

Papadi from each selection were weighed before and after deep frying in an electronic balance. Before measuring the weight after frying, the Papadi were wiped with tissue paper to remove the adhering surface oil. The difference in weight was worked out and expressed as oil uptake in percentage.

\subsubsection{Expansion ratio}

The expansion ratio of fried protein enriched Papadi will be calculated according to the procedure given below,

$$
\text { Expansion ratio }=\frac{\mathrm{DF}-\mathrm{DR}}{\mathrm{DR}} \times 100
$$

\section{Where \\ $\mathrm{DF}=$ Diameter of fried protein enriched cereal based traditional products \\ $\mathrm{DR}=$ Diameter of raw protein enriched cereal based traditional products}

\subsubsection{Textural properties of fried protein enriched papadi}

The textural properties of fried protein enriched papadi by incorporation of WPC was evaluated. Stable Micro System TAXT2 plus Texture Analyzer was used for texture profile analysis (TPA) of protein enriched papadi prepared by lab sample. A spherical-end probe of $6.35 \mathrm{~mm}$ of diameter with test speed of $1 \mathrm{~mm} / \mathrm{sec}$. of pre-test and post-test speeds; and 50 per cent compression was taken for TPA analysis. TPA is "two-bite" test, which includes the first and second compression cycles. The first and second compression cycles indicate the force vs. time data during the first and second compression of the product by the instrument probe. There were four replications of the instrumental analysis conducted on separate days. For each replication, papadi incorporated with different proportions of WPC were evaluated.

\subsection{Statistical analysis}

The data obtained was analyzed using Completely Randomize Design (Panse and Sukhatme, 1967).

\section{Results and Discussion}

3.1. Effect of whey protein concentrate on chemical composition of Jowar batter

The moisture content of Jowar Batter increased from 63.28 $\left(\mathrm{T}_{0}\right)$ to $70.20\left(\mathrm{~T}_{4}\right)$ per cent. The highest fat $(1.68 \%)$ was observed in $\mathrm{T}_{4}$ (10 parts WPC supplemented Jowar Batter) while lowest $(0.83 \%)$ was observed in $\mathrm{T}_{0}$ (control sample). The highest protein $\left(11.28 \%\right.$ ) was observed in $\mathrm{T}_{4}$ (10 parts WPC supplemented Jowar Batter) while lowest (4.63\%) was observed in $\mathrm{T}_{0}$ (control sample). Ash content of Jowar Batter increased slightly from 0.36 to 0.48 per cent. The lowest carbohydrate $(16.38 \%)$ was observed in $\mathrm{T}_{4}$ (10 parts WPC supplemented Jowar Batter) while highest (30.91\%) was observed in $\mathrm{T}_{0}$ (control sample). Results also showed that an increase in the WPC supplementation level, increase the moisture, fat, protein and ash content also decreases the carbohydrate content of the product. Above results are closely related with Wani et al. (2015) ${ }^{[20]}$. According to them with an increase in the WPC supplementation level, there was increase in moisture, protein, ash and fat content and total carbohydrate decreases. It was also observed that as the addition of WPC level increases, the $\mathrm{pH}$ of Jowar Batter decreased. This might be due to WPC supplementation increases the acidity of Jowar Batter as compared to control. According to Nale (2016) ${ }^{[14]}$. Maximum $\mathrm{pH}$ was observed for $\mathrm{T}_{1}$ Bajra Groat prepared using water as soaking agent for 12 hrs. (6.4) and minimum for $\mathrm{T}_{5}$ Bajra Groat prepared using chakka whey as soaking agent for $20 \mathrm{hrs}$. (5.7). He also concluded that titratable acidity of bajra groats prepared from chakka whey as soaking agent was more as compared to the bajra groat used water as soaking agent.

\subsection{Effect of WPC on Physical properties of Raw Jowar Papadi}

It was revealed from the above table that the total number of Jowar Papadi samples was ranged between 23.25 and 25.75. Highest number (25.75) was noted for $\mathrm{T}_{4}$ prepared using 10 parts of WPC and lowest (23.25) for $\mathrm{T}_{0}$ prepared without addition of WPC. This might be due to soaking effect of grains, water binding property of WPC and cooking parameters.

\subsection{Effect of WPC on chemical composition of Raw Jowar Papadi}

As shown in Table 4, the moisture content of Jowar Papadi increased from 3.95 to 4.95 per cent. Highest moisture content $(4.95 \%)$ was observed in $\mathrm{T}_{4}$ (10 parts WPC supplemented Jowar Papadi), while the lowest moisture content (3.95\%) was found for $T_{0}$ (control sample). Results showed that moisture content of all the treatments differ significantly. Increase in moisture content with increasing WPC supplementation level may be due to more bound water in the system. These results are in accordance with Gallagher et al. (2005) ${ }^{[7]}$. Who reported that biscuits supplemented with WPC were higher in moisture content compared with control Biscuits. Also Wani et al. (2015) ${ }^{[20]}$, showed that with an increase in the WPC supplementation level, there was increase in moisture. Fat content of Jowar Papadi increased 
from 1.14 to 2.13 per cent. This might be due to high fat content in WPC as compared with Jowar grains. Results are related with Parate et al. (2011) ${ }^{[16]}$. observed that biscuits fortified with Whey Protein Concentrate had fat content slightly greater than the control biscuits as well as Wani et al. (2015) ${ }^{[20]}$, revealed that 6 per cent WPC supplemented cookies shows maximum fat content (23.08\%) as compared to control. The Jowar Papadi prepared from 10 parts of WPC supplementation $\left(\mathrm{T}_{4}\right)$ gave numerically higher level of protein percentage followed by $\mathrm{T}_{3}, \mathrm{~T}_{2}, \mathrm{~T}_{1}$ and $\mathrm{T}_{0}$. Results also showed that with an increase in the WPC supplementation level, there was increase in the protein content of the product. This might be due to high protein content in WPC. Wani et al. (2015) [20], observed that the Protein content in cookies increased from 9.08 to 13.22 per cent with an increase in the WPC supplementation level. Nale (2016) ${ }^{[14]}$. reported that the protein content of bajra groat increased when the bajra groat prepared using chakka whey as soaking agent for $12 \mathrm{hrs}$. The highest ash $(3.08 \%)$ was observed in $\mathrm{T}_{4}$ (10 parts WPC supplemented Jowar Papadi) while lowest (2.16\%) was observed in $\mathrm{T}_{0}$ (control sample). This might be due to high ash content in WPC as compared with Jowar grains. Munaza et al. (2012) ${ }^{[13]}$. Revealed that ash content of the experimental biscuit samples increased with the level of incorporation of whey protein concentrate. Wani et al. (2015) ${ }^{[20]}$, observed that ash content in cookies increased from 0.96 to 2.02 per cent with an increase in the WPC supplementation level. Carbohydrate content of Jowar Papadi decreased from 81.74 to 71.07 per cent. Carbohydrate content of Jowar Papadi decreased from 81.74 to 71.07 per cent.

\subsection{Effect of WPC on Organoleptic Properties Fried Jowar Papadi}

The fried Jowar papadi were subjected to the sensory evaluation for flavour, body and texture, colour and appearance and overall acceptability attributes by a panel of trained judges (Gupta, 1976) ${ }^{[8]}$. The maximum flavour score (8.52) was received for fried Jowar Papadi prepared using 5 parts of WPC and minimum score (7.77) for the samples prepared using 10 parts of WPC. The addition of WPC improved the flavor score of fried Jowar Papadi up to supplementation of 5 parts of WPC but decreased thereafter. The Body and Texture score of fried Jowar Papadi for different treatments ranged between 7.78 and 8.59. The maximum score (8.56) was obtained for fried Jowar Papadi prepared using 5 parts of WPC and minimum score (7.98) was obtained for the fried Jowar Papadi prepared using 10 parts of WPC. The highest score was observed for fried Jowar Papadi samples of the treatment $\mathrm{T}_{2}$ (8.55) prepared using 5 parts of WPC and minimum score was obtained for $\mathrm{T}_{4}(7.84)$ in Jowar Papadi with 10 parts of WPC. The overall acceptability score for the Jowar Papadi with 5 parts WPC $\left(\mathrm{T}_{2}\right)$ was significantly $(P<0.05)$ superior over all treatment. Variation in overall acceptability score may be due to fermented batter, frying conditions and durations of soaking. According to Jooyandeh et al. (2009) ${ }^{[10]}$ the sensory scores of samples supplemented with 25 and 50\% WP had significantly higher score for appearance, crust colour, aroma, taste, texture and overall acceptability as compare to control, but at higher level of substitution deleterious effects was observed on sensory characteristics of bread. The results obtained are in close agreement with Wani et al. (2015) ${ }^{[20]}$. The mean score regarding overall acceptability of cookies revealed that $T_{2}$ (4\% WPC supplemented cookies) got the maximum score
(4.76), while $\mathrm{T}_{3}$ (6\% WPC supplemented cookies) obtained minimum score (3.38).

\subsection{Effect of WPC on physical properties of fried Jowar Papadi}

The oil absorption of fried samples of Jowar Papadi was ranged from 22.82 to 26.40 per cent. Expansion ratio of fried Jowar Papadi shows an increasing trend from lowest $(28.39 \%)$ observed in control fried Jowar Papadi $\left(\mathrm{T}_{0}\right)$ to highest $(37.62 \%)$ found in 10 parts of WPC supplemented fried Jowar Papadi $\left(\mathrm{T}_{4}\right)$. Gaikwad et al. (2016) ${ }^{[6]}$. found that the highest expansion ratio was observed when the oil content was more in the black gram papad due to the high moisture content in raw papad.

\subsection{Effect of WPC on colour of fried Jowar Papadi}

The lightness $\left(\mathrm{L}^{*}\right)$ value of fried Jowar Papadi decreased from 65.89 to 56.86. The highest $L^{*}$ value (65.89) was observed in control fried Jowar Papadi $\left(\mathrm{T}_{0}\right)$ and lowest (56.86) was observed in 10 parts of WPC supplemented fried Jowar Papadi $\left(\mathrm{T}_{4}\right)$, which is due to the development of coloured compounds through the Maillard reaction between the WPC, lactose and the free amino groups. The Redness/greenness of fried Jowar Papadi shows an increasing trend. The lowest value (1.63) was observed in control fried Jowar Papadi $\left(\mathrm{T}_{0}\right)$ and the highest value (8.54) was found in 10 parts of WPC supplemented fried Jowar Papadi $\left(\mathrm{T}_{4}\right)$. The increase in redness of fried Jowar Papadi could be attributed to darkening of WPC during frying at high temperature. The $b^{*}$ value of the samples ranges between 21.67 and 31.79 . It was observed that the yellowness of fried Jowar Papadi increases from control sample $\left(\mathrm{T}_{0}\right)$ to 10 parts of WPC supplemented sample $\left(\mathrm{T}_{4}\right)$ which may be attributed to degradation of compounds during frying. Results are closely related with Wani et al. (2015) ${ }^{[20]}$, which observed L* value in cookies decreased and Redness/greenness $\left(\mathrm{a}^{*}\right)$ as well as yellowness of cookies $\left(b^{*}\right.$-value) increased with increasing the WPC supplementation.

\subsection{Effect of WPC on textural properties of fried Jowar Papadi}

It was revealed from the table 8 that hardness of fried Jowar Papadi in peak positive force was ranged from 0.15 to 0.34 Kg. Maximum hardness was observed for fried Jowar Papadi prepared using 10 parts of WPC $(0.34 \mathrm{Kg})$ and minimum for fried Jowar Papadi prepared by without addition of WPC $(0.15 \mathrm{Kg})$. Hardness of fried Jowar Papadi in peak positive force was increases as the incorporation of WPC increases from 0 to 10 parts. Present results are in agreement with Wani et al. (2015) ${ }^{[20]}$. Indicated that, the highest peak force was observed in $6(\%)$ WPC supplemented cookies $(55.3 \mathrm{~N})$, followed by control cookies $(50.2 \mathrm{~N})$. Maximum Fracturability was observed for fried Jowar Papadi prepared using 10 parts of WPC $(0.228 \mathrm{~mm})$ and minimum for fried Jowar Papadi prepared without addition of WPC $(0.120 \mathrm{~mm})$. Fracturability of fried Jowar Papadi increased as the incorporation of WPC increases from 0 to 10 parts.

\subsection{Effect of WPC on microbial properties of raw Jowar Papadi \\ 3.8.1. Total plate count}

It is revealed from table 2 that 30 days of storage the Total plate count was found in $\mathrm{T}_{3}\left(0.25 \times 10^{2} \mathrm{CFU} / \mathrm{g}\right)$ as well as in $\mathrm{T}_{4}\left(0.50 \times 10^{2} \mathrm{CFU} / \mathrm{g}\right)$ and absent in $\mathrm{T}_{2}, \mathrm{~T}_{1}$ and $\mathrm{T}_{0}$. At 60 days of storage TPC was found in $T_{2}, T_{3}$ as well as in $T_{4}$ but 
absent in $T_{0}$ and $T_{1}$. From Table 2 , it can be concluded that after 90 days of storage the samples of Jowar papadi with 10 parts of WPC supplemented $\left(\mathrm{T}_{4}\right)$ tend to have higher mean total plate counts than those with $\mathrm{T}_{3}, \mathrm{~T}_{2}, \mathrm{~T}_{1}$ and $\mathrm{T}_{0}$. The maximum for total plate count on nutrient agar was observed in $\mathrm{T}_{4}$ (10 parts WPC supplemented Jowar papadi) and minimum in $\mathrm{T}_{0}$ (control Jowar papadi) for 90, 120, 150 and 180 days of storage period. Results revealed that the total plate count of all samples does not differ significantly. The increase in microbial load of WPC supplemented Jowar papadi as compared to control may be due to increase in moisture content with increasing WPC supplementation level. The growths of TPC were in increasing order as storage period increased. As per the WHO (1994) guideline the total plate count should be less than $2 \times 10^{5} / \mathrm{g}$. The result of this study in respect of TPC was in acceptable limit. Borkar et al. (2014) reported the maximum shelf life of sorgo papad viz. Sondoli and Bibadi was estimated to be 210 and 220 days respectively at $30{ }^{\circ} \mathrm{C}$ under saturated conditions while packed in HDPE (Thickness $=0.036 \mathrm{~mm}$ ). The results were in good accordance with results reported by Wani et al. (2015) ${ }^{[20]}$. the maximum total microbial load on nutrient agar $\left(4.62 \times 10^{2}\right)$ was observed in $\mathrm{T}_{3}$ (6\% WPC supplemented cookies) and minimum $\left(3.05 \times 10^{2}\right)$ was observed in $\mathrm{T}_{0}$ (control cookies).

\subsubsection{Yeast and mold count}

From table 3, it was observed that there is no growth of yeast and mold at 0 days. After 30 days of storage yeast and mold count was observed only in treatment $\mathrm{T}_{4}\left(0.25 \times 10^{2} \mathrm{CFU} / \mathrm{g}\right)$. After 60 days of storage yeast and mold count was observed in $\mathrm{T}_{3}$ and $\mathrm{T}_{4}$ and absent in $\mathrm{T}_{0}, \mathrm{~T}_{1}$ and $\mathrm{T}_{2}$. After 90 days of storage yeast and mold count was absent only in control treatment. At 120 days of storage the samples of Jowar papadi with 10 parts of WPC supplemented $\left(\mathrm{T}_{4}\right)$ tend to have higher mean yeast and mold counts than those with $\mathrm{T}_{3}, \mathrm{~T}_{2}, \mathrm{~T}_{1}$ and $\mathrm{T}_{0}$. The maximum yeast and mold count was observed in $\mathrm{T}_{4}$ (10 parts WPC supplemented Jowar papadi) and minimum in $\mathrm{T}_{0}$ (control Jowar papadi) for 120,150 and 180 days of storage. Results of this study revealed that the yeast and mold count of all samples does not differ significantly. The increase in yeast and mold count of WPC supplemented Jowar papadi as compared to control may be due to increase in moisture content with increasing WPC supplementation level. As per the WHO (1994) guideline the Yeast and mold count should be less than $1 \times 10^{4} / \mathrm{g}$. Above results related to yeast and mold count was within the acceptable limit. Wani et al. (2015) ${ }^{[20]}$. observed the maximum fungal count $\left(0.13 \times 10^{3}\right)$ was observed in $\mathrm{T}_{3}$ (6\% WPC supplemented cookies) while lowest $\left(0.5 \times 10^{1}\right)$ was found in $\mathrm{T}_{0}$ (control cookies).

\subsubsection{Coliform count}

Coliform count was absent throughout the study period indicating the degree of hygienic conditions maintained during product development and storage.

Table 1: Chemical composition of WPC and Jowar Grains

\begin{tabular}{|c|c|c|c|}
\hline Sr. no & Composition & WPC Powder & Jowar Grains \\
\hline 1 & Total Solid (\%) & 96.96 & 88.00 \\
\hline 2 & Ash (\%) & 6.20 & 2.06 \\
\hline 3 & Moisture (\%) & 3.04 & 12.00 \\
\hline 4 & Protein (\%) & 70.85 & 15.08 \\
\hline 5 & Fat (\%) & 6.50 & 4.04 \\
\hline 6 & Carbohydrates (\%) & - & 66.77 \\
\hline 7 & NPN (\%) & 0.18 & - \\
\hline 8 & Calcium (\%) & 1.70 & - \\
\hline 9 & Chloride (\%) & 1.57 & - \\
\hline 10 & Acidity (\% Lactic acid) & 1.62 & \\
\hline
\end{tabular}

Rathour et al. (2016) and Butti et al. (2017)

Table 2: Effect of WPC on chemical composition of Jowar Batter

\begin{tabular}{|c|c|c|c|c|c|c|c|}
\hline Treatments & Moisture \% & Fat \% & Protein \% & Ash \% & Carbohydrate \% & pH & Titratable Acidity \% \\
\hline $\mathrm{T}_{0}$ & $63.28^{\mathrm{a}}$ & $0.83^{\mathrm{a}}$ & $4.63^{\mathrm{a}}$ & $0.36^{\mathrm{a}}$ & $30.91^{\mathrm{a}}$ & $4.68^{\mathrm{a}}$ & $0.76^{\mathrm{a}}$ \\
\hline $\mathrm{T}_{1}$ & $64.89^{\mathrm{b}}$ & $0.98^{\mathrm{b}}$ & $5.93^{\mathrm{b}}$ & $0.39^{\mathrm{b}}$ & $27.71^{\mathrm{b}}$ & $4.44^{\mathrm{b}}$ & $0.95^{\mathrm{b}}$ \\
\hline $\mathrm{T}_{2}$ & $66.56^{\mathrm{c}}$ & $1.18^{\mathrm{c}}$ & $7.15^{\mathrm{c}}$ & $0.42^{\mathrm{c}}$ & $24.63^{\mathrm{c}}$ & $4.26^{\mathrm{c}}$ & $1.14^{\mathrm{c}}$ \\
\hline $\mathrm{T}_{3}$ & $68.26^{\mathrm{d}}$ & $1.38^{\mathrm{d}}$ & $8.31^{\mathrm{d}}$ & $0.45^{\mathrm{d}}$ & $21.61^{\mathrm{d}}$ & $4.02^{\mathrm{d}}$ & $1.33^{\mathrm{d}}$ \\
\hline $\mathrm{T}_{4}$ & $70.20^{\mathrm{e}}$ & $1.68^{\mathrm{e}}$ & $11.28^{\mathrm{e}}$ & $0.48^{\mathrm{e}}$ & $16.38^{\mathrm{e}}$ & $3.87^{\mathrm{e}}$ & $1.54^{\mathrm{e}}$ \\
\hline SE & 0.45 & 0.01 & 0.04 & 0.01 & 0.44 & 0.01 & 0.01 \\
\hline CD at 5\% & 1.35 & 0.04 & 0.12 & 0.02 & 1.31 & 0.02 & 0.03 \\
\hline
\end{tabular}

Table 3: Effect of WPC on Physical properties of Raw Jowar Papadi

\begin{tabular}{|c|c|}
\hline Treatments & Total Number \\
\hline$T_{0}$ & 23.25 \\
\hline$T_{1}$ & 23.75 \\
\hline$T_{2}$ & 24.50 \\
\hline$T_{3}$ & 25.00 \\
\hline$T_{4}$ & 25.75 \\
\hline$S E$ & 0.60 \\
\hline$C D$ at $5 \%$ & 1.79 \\
\hline
\end{tabular}


Table 4: Effect of WPC on chemical composition of Raw Jowar Papadi

\begin{tabular}{|c|c|c|c|c|c|}
\hline $\begin{array}{c}\text { Treatments } \\
\mathbf{\%}\end{array}$ & $\begin{array}{c}\text { Moisture } \\
\boldsymbol{\%}^{\mathrm{a}}\end{array}$ & $\begin{array}{c}\text { Fat } \\
\mathbf{\%}\end{array}$ & $\begin{array}{c}\text { Protein } \\
\mathbf{\%}\end{array}$ & $\begin{array}{c}\text { Ash } \\
\mathbf{\%}\end{array}$ & $\begin{array}{c}\text { Carbohydrate } \\
\mathbf{\%}\end{array}$ \\
\hline $\mathrm{T}_{0}$ & $3.95^{\mathrm{a}}$ & $1.14^{\mathrm{a}}$ & $11.07^{\mathrm{a}}$ & $2.16^{\mathrm{a}}$ & $81.74^{\mathrm{a}}$ \\
\hline $\mathrm{T}_{1}$ & $4.19^{\mathrm{b}}$ & $1.40^{\mathrm{b}}$ & $13.14^{\mathrm{b}}$ & $2.43^{\mathrm{b}}$ & $78.88^{\mathrm{b}}$ \\
\hline $\mathrm{T}_{2}$ & $4.51^{\mathrm{c}}$ & $1.81^{\mathrm{c}}$ & $15.77^{\mathrm{c}}$ & $2.63^{\mathrm{c}}$ & $75.30^{\mathrm{c}}$ \\
\hline $\mathrm{T}_{3}$ & $4.70^{\mathrm{d}}$ & $2.02^{\mathrm{d}}$ & $17.27^{\mathrm{d}}$ & $2.85^{\mathrm{d}}$ & $73.29^{\mathrm{d}}$ \\
\hline $\mathrm{T}_{4}$ & $4.95^{\mathrm{e}}$ & $2.13^{\mathrm{e}}$ & $18.78^{\mathrm{e}}$ & $3.08^{\mathrm{e}}$ & $71.07^{\mathrm{e}}$ \\
\hline $\mathrm{SE}$ & 0.06 & 0.01 & 0.03 & 0.06 & 0.11 \\
\hline $\mathrm{CD}$ at $5 \%$ & 0.17 & 0.02 & 0.09 & 0.19 & 0.33 \\
\hline
\end{tabular}

Table 5: Effect of WPC on Organoleptic Properties Fried Jowar Papadi

\begin{tabular}{|c|c|c|c|c|}
\hline Treatments Flavour & $\begin{array}{c}\text { Body and } \\
\text { Texture }\end{array}$ & $\begin{array}{c}\text { Colour and } \\
\text { Appearance }\end{array}$ & $\begin{array}{c}\text { Overall } \\
\text { Acceptability }\end{array}$ \\
\hline $\mathrm{T}_{0}$ & $8.35^{\mathrm{a}}$ & $8.36^{\mathrm{a}}$ & $8.40^{\mathrm{a}}$ & $8.37^{\mathrm{a}}$ \\
\hline $\mathrm{T}_{1}$ & $8.27^{\mathrm{a}}$ & $8.23^{\mathrm{b}}$ & $8.24^{\mathrm{b}}$ & $8.22^{\mathrm{b}}$ \\
\hline $\mathrm{T}_{2}$ & $8.52^{\mathrm{b}}$ & $8.59^{\mathrm{c}}$ & $8.56^{\mathrm{c}}$ & $8.55^{\mathrm{c}}$ \\
\hline $\mathrm{T}_{3}$ & $8.15^{\mathrm{c}}$ & $8.12^{\mathrm{d}}$ & $8.13^{\mathrm{d}}$ & $8.16^{\mathrm{d}}$ \\
\hline $\mathrm{T}_{4}$ & $7.77^{\mathrm{d}}$ & $7.78^{\mathrm{e}}$ & $7.98^{\mathrm{e}}$ & $7.84^{\mathrm{e}}$ \\
\hline $\mathrm{SE}$ & 0.03 & 0.03 & 0.03 & 0.02 \\
\hline CD at $5 \%$ & 0.10 & 0.09 & 0.10 & 0.05 \\
\hline
\end{tabular}

Table 6: Effect of WPC on Physical properties of fried Jowar Papadi

\begin{tabular}{|c|c|c|}
\hline Treatments & Oil Absorption \% & Expansion Ratio \% \\
\hline $\mathrm{T}_{0}$ & $22.82^{\mathrm{a}}$ & $28.39^{\mathrm{a}}$ \\
\hline $\mathrm{T}_{1}$ & $23.33^{\mathrm{b}}$ & $30.17^{\mathrm{b}}$ \\
\hline $\mathrm{T}_{2}$ & $24.74^{\mathrm{c}}$ & $33.04^{\mathrm{c}}$ \\
\hline $\mathrm{T}_{3}$ & $25.24^{\mathrm{d}}$ & $35.36^{\mathrm{d}}$ \\
\hline $\mathrm{T}_{4}$ & $26.40^{\mathrm{e}}$ & $37.62^{\mathrm{e}}$ \\
\hline $\mathrm{SE}$ & 0.05 & 0.04 \\
\hline $\mathrm{CD}$ at $5 \%$ & 0.14 & 0.11 \\
\hline
\end{tabular}

Table 7: Effect of WPC on Colour of Fried Jowar Papadi

\begin{tabular}{|c|c|c|c|}
\hline Treatments & $\left(\mathbf{L}^{*}\right)$ Lightness & $\left(\mathbf{a}^{*}\right)$ Redness & $\left(\mathbf{b}^{*}\right)$ Yellowness \\
\hline $\mathrm{T}_{0}$ & $65.89^{\mathrm{a}}$ & $1.63^{\mathrm{a}}$ & $21.67^{\mathrm{a}}$ \\
\hline $\mathrm{T}_{1}$ & $64.73^{\mathrm{b}}$ & $4.74^{\mathrm{b}}$ & $24.37^{\mathrm{b}}$ \\
\hline $\mathrm{T}_{2}$ & $63.25^{\mathrm{c}}$ & $5.34^{\mathrm{c}}$ & $26.87^{\mathrm{c}}$ \\
\hline $\mathrm{T}_{3}$ & $59.90^{\mathrm{d}}$ & $7.26^{\mathrm{d}}$ & $29.83^{\mathrm{d}}$ \\
\hline $\mathrm{T}_{4}$ & $56.86^{\mathrm{e}}$ & $8.54^{\mathrm{e}}$ & $31.79^{\mathrm{e}}$ \\
\hline $\mathrm{SE}$ & 0.22 & 0.02 & 0.07 \\
\hline CD at $5 \%$ & 0.65 & 0.07 & 0.21 \\
\hline
\end{tabular}

Table 8: Effect of WPC on Textural Properties of Fried Jowar Papadi

\begin{tabular}{|c|c|c|}
\hline Treatments & Hardness (force in Kg) & Factorability $(\mathbf{m m})$ \\
\hline $\mathrm{T}_{0}$ & $0.15^{\mathrm{a}}$ & $0.120^{\mathrm{a}}$ \\
\hline $\mathrm{T}_{1}$ & $0.19^{\mathrm{b}}$ & $0.148^{\mathrm{b}}$ \\
\hline $\mathrm{T}_{2}$ & $0.23^{\mathrm{c}}$ & $0.168^{\mathrm{b}}$ \\
\hline $\mathrm{T}_{3}$ & $0.29^{\mathrm{d}}$ & $0.203^{\mathrm{c}}$ \\
\hline $\mathrm{T}_{4}$ & $0.34^{\mathrm{e}}$ & $0.228^{\mathrm{c}}$ \\
\hline SE & 0.01 & 0.01 \\
\hline CD at $5 \%$ & 0.03 & 0.03 \\
\hline
\end{tabular}

Table 9: Effect of WPC on TPC (X $\left.10^{2} \mathrm{CFU} / \mathrm{g}\right)$ of Raw Jowar Papadi

\begin{tabular}{|c|c|c|c|c|c|c|c|}
\hline \multirow{2}{*}{ Treatment } & \multicolumn{7}{|c|}{ Storage Period in days } \\
\cline { 2 - 8 } & 00 & 30 & 60 & 90 & 120 & 150 & 180 \\
\hline $\mathrm{T}_{0}$ & 00 & 0.00 & 0.00 & 0.25 & 1.00 & 1.75 & 2.75 \\
\hline $\mathrm{T}_{1}$ & 00 & 0.00 & 0.00 & 0.50 & 1.75 & 3.00 & 4.50 \\
\hline $\mathrm{T}_{2}$ & 00 & 0.00 & 0.25 & 1.00 & 2.50 & 4.25 & 6.00 \\
\hline $\mathrm{T}_{3}$ & 00 & 0.25 & 0.50 & 1.50 & 3.00 & 4.75 & 7.00 \\
\hline $\mathrm{T}_{4}$ & 00 & 0.50 & 1.00 & 2.00 & 4.50 & 6.75 & 8.25 \\
\hline $\mathrm{SE}$ & 00 & 0.17 & 0.17 & 0.21 & 0.28 & 0.34 & 0.38 \\
\hline $\mathrm{CD}$ at $5 \%$ & 00 & 0.51 & 0.51 & 0.65 & 0.85 & 1.03 & 1.13 \\
\hline
\end{tabular}

Table 10: Effect of WPC on Yeast and Mold (X $\left.10^{2} \mathrm{CFU} / \mathrm{g}\right)$ count of Raw Jowar Papadi

\begin{tabular}{|c|c|c|c|c|c|c|c|}
\hline \multirow{2}{*}{ Treatment } & \multicolumn{7}{|c|}{ Storage Period in days } \\
\cline { 2 - 9 } & 00 & 30 & 60 & 90 & 120 & 150 & 180 \\
\hline $\mathrm{T}_{0}$ & 00 & 0.00 & 0.00 & 0.00 & 0.50 & 1.00 & 2.00 \\
\hline $\mathrm{T}_{1}$ & 00 & 0.00 & 0.00 & 0.25 & 0.75 & 1.75 & 2.75 \\
\hline $\mathrm{T}_{2}$ & 00 & 0.00 & 0.00 & 0.50 & 1.00 & 2.00 & 3.25 \\
\hline $\mathrm{T}_{3}$ & 00 & 0.00 & 0.50 & 0.75 & 1.50 & 2.50 & 3.75 \\
\hline $\mathrm{T}_{4}$ & 00 & 0.25 & 0.75 & 1.00 & 2.00 & 2.75 & 4.25 \\
\hline $\mathrm{SE}$ & 00 & 0.11 & 0.25 & 0.27 & 0.38 & 0.38 & 0.34 \\
\hline $\mathrm{CD}$ at $5 \%$ & 00 & 0.34 & 0.75 & 0.83 & 1.15 & 1.15 & 1.03 \\
\hline
\end{tabular}

\section{Conclusion}

In view of experimental results obtained during the present investigation, it may be concluded that the fried Jowar Papadi prepared with 5 parts of WPC received highest score for flavor, body and texture, colour and appearance and overall acceptability was liked very much by the judges in the organoleptic evaluation. WPC supplementation affected textural characteristic of fried Papadi, the hardness and Fracturability increases with increase in the WPC level. In Physical properties of raw papadi, total number slightly increases as the WPC supplementation level increase. WPC also affected on physical properties of fried papadi. In colour characteristics, Lightness value of fried Jowar Papadi decreased as the WPC level increased which is due to the development of colored compounds through the Maillard reaction. Redness as well as yellowness of fried Jowar Papadi increases with an increase in the WPC level which may be attributed to darkening of WPC and degradation of compounds during frying at high temperature. Oil absorption and Expansion ratio increased as the WPC level increased, variation might be due to varied moisture content in dried Papadi samples. WPC incorporation affected chemical characteristic of Jowar Batter. Significant increase in moisture, fat, protein and ash per cent but decrease in carbohydrate content was observed when incorporation level of WPC increased. Increase in WPC supplementation there was decreases $\mathrm{pH}$ and increases titratable acidity of Jowar Batter. Results also showed that with an increase in the WPC supplementation level, in Jowar Papadi, samples there was increase in moisture, protein, ash and fat content and total carbohydrate decreases. From the present study, it can be concluded that the 10 parts WPC supplemented papadi samples were nutritionally rich. As supplementation of WPC increases microbial quality such as TPC and yeast and mold increased in Jowar Papadi. Coliform count was found to be absent throughout the study period indicating the degree of hygienic conditions maintained during product development. The TPC and Yeast and mold count in all samples for period of six months was found within acceptable limits. The study concluded that supplementation level of 5 parts of WPC in Jowar papadi results in acceptable sensory, textural, microbial and nutritional characteristics.

\section{References}

1. AOAC. International Official Method of Analysis, Trends Food Science Technology. Association of Official Analytical Chemists, Washington, D.C. USA, 1990.

2. Borkar PA, Rajput MR, Murumkar RP, Dange MM. Development of Standardized and Modified Process Technology for Making Sorgo-papad (Sandoli and Bibadi). Journal of Ready to eat Food. 2014; 1(2):69-77.

3. Butti P, More DR, Srilatha P, Chavan RF. Screening of Sorghum Varieties for Papad Preparation. International 
Journal of Current Microbiology and Applied Sciences, 2017; 6(7):1116-1124.

4. Chatterjee A, Kanawjia SK. Whey Proteins for Healthy Living. Indian Dairyman, 2010, 66-73.

5. Chavan JK, Kadam SS. Critical Reviews in Food Science and Nutrition. Food Sci. 1989; 28:348-400.

6. Gaikwad PS, Koli JP, Pare A. Impact of Various Drying Techniques to Reduce Oil Absorption in Black Gram Papad. International Journal of Science, Environment and Technology. 2016; 5(3):1630-1637.

7. Gallagher E, Kenny S, Arendt EK. Impact of Dairy Protein Powders on Biscuit Quality. European Food Research Technology. 2005; 221:237-243.

8. Gupta SK. Sensory Evaluation in Food. Indian Dairyman. 1976; 28(8):293.

9. Hamad AM, Fields ML. Evaluation of Protein Quality and Available Lysine of Germinated and Ungerminated Cereals. J of Food Sci. and Technol. 1979; 44:456-459.

10. Jooyandeh H, Minhas KS, Kaur A. Sensory Quality and Chemical Composition of Wheat Breads Supplemented with Fermented Whey Protein Concentrate and Whey Permeate. J Food Sci. and Technol. 2009; 46(2):146-148.

11. Malik S. Pearl Millet Nutritional Value and Medicinal Uses. IJARIIE-ISSN (O). 2015; 1(3):414-418.

12. Mitha S, Mogra R. Quality Evaluation of Value Added Vermicelli. J. Foood Sci. Technol. 2007; 44(2):220-223.

13. Munaza B, Prasad SGM, Gayas B. Whey Protein Concentrate Enriched Biscuits. Int. J of Scientific and Research Publications, 2012, 2.

14. Nale NK. Utilization of Chakka Whey as Soaking Agent in Prepartion of Kharudi. M.Sc. Thesis submitted in VNMKV, Parbhani, 2016.

15. Panse YP, Sukatme PV. Statistical Methods for Agricultural Workers, $2^{\text {nd }}$ edn. Indian Council of Agricultural Research, New Delhi, 1961.

16. Parate VR, Kawadkar DK, Sonawane SS. Study of Whey Protein Concentrate Fortification in Cookies Variety Biscuits. International Journal of Food Engineering. 2011; 7(2):1-11.

17. Rathour AK, Rathore V, Mehta BM, Patel SM, Chauhan A, Aparnathi KD et al. Standardization and Storage Study of Whey Protein Concentrate (WPC-70) Prepared From Buffalo Milk Using Ultrafiltration Membrane Technology. Journal of Food Processing and Preservation. 2016; 41:1-8.

18. Rekha. In: Proc. $2^{\text {nd }}$ National Seminar on Home Science for Rural Development in $21^{\text {st }}$ Century, 1999, 410-415.

19. Rolle R, Satin M. Basic Requirements for the Transfer of Fermentation Technologies to Developing Countries. Int. J Food Microbial. 2002; 75:181-187.

20. Wani SH, Gull A, Allaie F, Safapuri TA. Effects of Incorporation of Whey Protein Concentrate on Physicochemical, Texture and Microbial Evaluation of Developed Cookies. Cogent Food and Agriculture, 2015, $1-9$.

21. WHO. Guidelines on Formulated Supplementary Foods for Older Infants and Young Children. Food Standards Program Codex Alimentarious Commission, 1994.

22. WHO (World Health Organization). Vitamin A supplementation in infants and children 6 to 9 months of age, 2011. 